\title{
4
}

\section{Laughing at the Other: Toward an Understanding of the Alt-Right with Adorno}

\section{Claudia Leeb}

\section{Introduction}

In the false society laughter is a disease which has attacked happiness and is drawing it in its worthless totality ${ }^{1}$

This paper draws on Theodor W. Adorno, in particular his critique on laughter fabricated by what the early Frankfurt School critical theory came to term the "culture industry," to arrive at an understanding of the growing appeal of the Alt-Right for young, mostly male millennials in the United States today. The term "Alt-Right" stands for "Alternative Right" and comprises a growing and still evolving predominantly on-line and

\footnotetext{
${ }^{1}$ Max Horkheimer and Theodor W. Adorno, Dialectic of Enlightenment, trans. John Cumming (New York: Continuum Publishing, 2002), p. 141.
}

\section{Leeb $(\bowtie)$}

Washington State University, Pullman, WA, USA

e-mail: claudia.leeb@wsu.edu 
anonymous white supremacist and anti-feminist movement, which was energized by the Trump electoral campaign. ${ }^{2}$ Its core aim is to create in the US something akin to the National Socialist Third Reich-a nation of white subjects, where all non-white subjects are expelled.

Adorno's critique on laughter is central to grasp the tools the Alt-Right is using to recruit new members to its extremist ideas, because it calls our attention to the ways in which laughter can function for both regressive and democratic political ends. Adorno's theorizing of laughter is in the line of classical and contemporary thinkers, who call our attention to laughter's subversive political possibilities and as enriching democratic politics. Particularly in Adorno's Aesthetic Theory and his essays on the plays of Samuel Becket and the movies of Charlie Chaplin, we find an account of laugher as a subversive political possibility.

However, Adorno also explains the ways in which laughter can function for regressive political ends. He helps balance out the picture that classical and contemporary theorists have provided in their theorizing about laughter, because he shows us how laughter can serve both regressive and democratic political ends. Insofar as I am interested in the ways in which laughter turns into a tool for regressive political ends, as a recruitment tool for the Alt-Right white-supremacist and anti-feminist movement, my focus is on Adorno's critical theorizing of laughter as it is fabricated by the culture industry.

To ground my theoretical elaborations with empirical examples, I draw on some of George Hawley's book Making Sense of the Alt-Right. ${ }^{3}$ I mostly draw on his book, because it provides in-depth interviews with Alt-Right members, and he most of the time "let's them speak" instead of offering much commentary on what Alt-Right members have to say, which provides useful material for further theoretical analysis. However, I disagree with Hawley's larger attempt in his book, which aims to show conservatives that they don't have to be associated with the Alt-Right, and in the process of doing so he covers up how much the Republican Party of the United States has contributed to foster the extremist ideas of the Alt-Right. ${ }^{4}$

\footnotetext{
2I will clarify the use of this terminology in the beginning of the next section.

${ }^{3}$ George Hawley, Making Sense of the Alt-Right (New York: Columbia University Press, 2017).

${ }^{4} \mathrm{I}$ am thankful to Joan Braune for this insight.
} 
My disagreement with Hawley becomes salient in relation to my argument of how the Alt-Right uses laughter and fun as a recruitment tool. Hawley, throughout the book, notes that the Alt-Right, in contrast to older white supremacist groups in the United States, offers to its (potential) members something else-namely laughter and fun. However, Hawley misses that it is also laughter and fun, in the form of racist and sexist jokes which Trump used throughout his electoral campaign and continues to use as a president to secure his base. This underlines a central connection between the Alt-Right and the Trump administration, and challenges Hawley's repeated insistence in the book that Trump has nothing to do with the Alt-Right. Furthermore, Hawley lacks a theoretical framework that would allow him to grasp the deeper psychological and economic factors that are at play in the rise of the Alt-Right.

The paper is set up in six sections. The first section "The Culture Industry of the Alt-Right" explains and draws upon Adorno's concept of the "culture industry" to get a better understanding of how the Alt-Right uses the internet to insert itself into mainstream politics. The second section, "The False Laughter of the Culture Industry," explains Adornos' critical theorizing of laugher produced by the culture industry. The third section, "The Fun of Desperation," explains the economic factors that make the "fun" produced by the Alt-Right a successful recruitment tool. The fourth section, "Jokes as the Regression to Inhumanity" aims to get a deeper understanding of the functioning of Alt-Right jokes in its recruitment tactics. The fifth section, "The Laughing Connection Between Trump and the Alt-Right," outline the ways in which laughter connects Trumpism and mainstream conservatism to the Alt-Right. The sixth and last section, "False Projections", draws on Adorno's writings on anti-Semitism to elaborate the ways in which the Alt-Right uses false projection as a recruitment tool, and how false projections are connected to its use of laughter.

\section{The Culture Industry of the Alt-Right}

In "Culture Industry Reconsidered" Adorno replaces the concept of "mass culture", which he used in earlier works, with the concept of the "culture 
industry" to exclude "from the outset the interpretation agreeable to its advocates," who would contend "that it is a matter of something like a culture that arises spontaneously from the masses themselves, the contemporary form of popular art." Instead, the culture industry, which Adorno studied in the United States during his exile from the German Nazi terror, erases any spontaneity in the masses-for the sake of profit it produces cultural goods according to plan with the intention of integrating consumers from above. The culture industry is not, as it would like to have us believe, "the art of the consumer," but rather the domination over the consumer. 6

Subjects do not have a so-called "free choice" to participate in the culture industry, which referred in the mid-twentieth century to Hollywood films, television shows, radio broadcasts, and print periodicals, as late capitalism suggests. Rather, the more the culture industry rules, the more everybody "must be acquainted with all the latest novelties if they are to continue living in a society rather than feeling themselves excluded from it. Mass culture allows precisely the reserve army of outsiders to participate: mass culture is an organized mania for connecting everything with everything else, a totality of public secrets. Everyone who is informed has his (/her) share in the secret, just as under National Socialism the privilege of esoteric blood-brotherhood was actually offered to everyone."7

Participation in the culture industry stands, according to Adorno, "under the sign of terror," and the subject who enthusiastically participates in the culture industry "not merely betrays an unconscious eagerness to read the commands from above but already reveals the fear of disobedience." 8 Adorno's repeated reference to fascism, which he uses at certain points interchangeably with the culture industry, does not mean, as Simon Jarvis points out, that Adorno conflated "the mass extermination of Jews on the one hand, and elements of implicit anti-semitism in American protofascism, on the other... His emphasis on the affinities between the culture industry and fascism is directed against the complacent assumption that

\footnotetext{
${ }^{5}$ Theodor W. Adorno, The Culture Industry: Selected Essays on Mass Culture, ed. J. M. Bernstein (London and New York: Routledge, 1991), p. 98.

${ }^{6}$ Adorno, The Culture Industry, 185.

${ }^{7}$ Adorno, The Culture Industry, 83.

${ }^{8}$ Adorno, The Culture Industry, 97.
} 
fascism is a uniquely German disorder, has nothing to do with capitalism, and 'could never happen here [in the United States]."'"

The most important effects of the culture industry are that they are producing certain kind of subjectivities, who have lost any imagination, or can only imagine what the culture industry prescribes. Insofar as an intact imagination is for Adorno the precondition for critical thinking, the culture industry produces a subject who fears any disobedience and eagerly subjects herself to commands from above-the potentially fascist subject. The growing attraction of the Alt-Right for young millennials in the United States today underscores the validity of Jarvis's argument, and underlines that fascism was not a uniquely German disorder and that such disorder in fact happens in the United States today.

The Alt-Right, which draws on aspects of the European radical right, finds inspiration from the Third Reich and, as Hawley points out, "thinks Hitler's model for government was generally correct; the primary problem with Nazi Germany was that it lost the war." ${ }^{\prime 10}$ To create in the US something akin to the National Socialist Third Reich, the Alt-Right proposes "policies" that range from massive violent ethnic cleansing to restrictions on nonwhite immigration. However, all of them agree on the necessity of creating a white ethno-state and that race is their most important goal. ${ }^{11}$ Also, akin to its National Socialist predecessors, the Alt-Right considers what they call in Anti-semitic fashion the "Jewish question" as its most important issue. ${ }^{12}$ Furthermore, the Alt-Right is also anti-feminist and considers gender as an important issue to address.

I then disagree with Hawley's use of the term "white nationalist" instead of "white supremacist", in his characterization of the Alt-Right, because, so he argues, the Alt-Right eschews the term "white supremacist" and prefers the term "white nationalist", "white separatist" and "identitarian". Furthermore, according to him, the term "white supremacist" would "mask the ways the Alt-Right differs from other manifestations of the racial

\footnotetext{
9Simon Jarvis, Adorno: A Critical Introduction (New York: Routledge, 1998), p. 63.

${ }^{10}$ Hawley, Making Sense of the Alt-Right, 36.

${ }^{11}$ Hawley, Making Sense of the Alt-Right, 16.

${ }^{12}$ Hawley, Making Sense of the Alt-Right, 28. Its best-known website is called the Daily Stormer, which is run by a neo-Nazi named Andrew Anglin.
} 
right. The Alt-Right is unlike any racist movement we have ever seen. It is atomized, amorphous, predominantly online, and mostly anonymous."13

However, the problem with Hawley's use of "white nationalist" is that he contributes to mask something else-the Alt-Right's belief, which it shares with its Nazi predecessors, that whites are somehow the superior race and that their overt hostility towards non-white people is central to their aim to create a white ethno-state. The Alt-Right prefers to use the term "white nationalist" to mask its white supremacist views, a masking that is reinforced by scholars, such as Hawley, who use "white nationalist" to characterize this movement. ${ }^{14}$

The Alt-Right has used a specific form of culture industry to insert itself into mainstream politics and gain visible presence in US American politics, which Adorno could have not foreseen-the internet. Alt-Right members are skilled at using the internet, and have a large number of blogs, podcasts, forums, on-line message boards, and webzines, which allows them to spread their extremist ideas. Hawley argues that the AltRight in its internet activity spontaneously responds to what is going on politically. ${ }^{15}$

Certainly, those who consume or follow their activity believe that they take part in the Alt-Right's supposed spontaneity. However, Adorno underlines that the culture industry eradicates any spontaneity, because total planning takes precedence over any spontaneity. Such planning entices the consumer of the culture industry to subjugate herself to whatever has been pre-ordained. The Alt-Right's internet culture industry contributes to "regression, blind complacency on the part of the subject encouraged to be spontaneous." 16 It is such blind complacency to its extremist ideas that the Alt-Right's internet culture industry seeks in its audience. How does it manage to do so?

The Alt-Right managed to inject itself successfully into the national conversation through what is called internet "trolling". Alt-Right "trolls" leave sites aimed at a right-wing audience and join discussions at other

\footnotetext{
${ }^{13}$ Hawley, Making Sense of the Alt-Right, 3.

${ }^{14}$ To do justice to Hawley, he does acknowledge both aspects of my critique on p. 13.

${ }^{15}$ Hawley, Making Sense of the Alt Right, 90.

${ }^{16}$ Adorno, The Culture Industry, 125.
} 
message boards, in, for example, the comment sections on major news venues, YouTube, and especially on Twitter. It thereby can circulate the movement's extremist views far beyond its own platforms. As Hawley explains: "An Internet troll is someone who fosters discord online, provoking strong emotional reactions from readers and often changing the topic of conversation". ${ }^{17}$

Furthermore, the Alt-Right uses so-called "internet memes" to spread its message. A meme is a major element in the internet-it is "simply an image, video, idea, hashtag, or slogan that spreads virally online. The most famous Internet memes tend to be innocuous, such as funny cat pictures." ${ }^{18}$ Although internet memes are seen as a "source of frivolous amusement", Alt-Right memes have a specific logic. A small cohort of Alt-Right supporters push memes via internet trolling, but they are spread across social media, especially Twitter, mostly by people who are not connected to the Alt-Right. ${ }^{19}$

Memes can introduce terms and concepts into popular discussion, even among people who do not use social media. As an example, a small number of Twitter users were responsible for spreading the false rumor that Hillary Clinton was in poor health, which was then embraced by people with no connection to the Alt-Right. ${ }^{20}$ How did it manage to spread such untruth? Adorno points out that the supposed "facts" the culture industry presents "are arranged in such a way that they can be grasped as quickly and easily as possible. Wrenched from all context, detached from thought, they are made instantly accessible to an infantile grasp." ${ }^{21}$

Also the internet memes produced by the Alt-Right are arranged in such a way that they can be grasped as quickly and easily as possible by an audience whose infantility the culture industry has already prepared. Their being wrenched from all context also assists that their false message is spread. Adorno makes clear that the "facts" presented by the culture industry must never be true. Rather, the culture industry's facts "tend towards deceit and the journalist's canard and the feeble invented anecdotes

\footnotetext{
${ }^{17}$ Hawley, Making Sense of the Alt-Right, 19.

${ }^{18}$ Hawley, Making Sense of the Alt-Right, 81 .

${ }^{19}$ Hawley, Making Sense of the Alt-Right, 82.

${ }^{20}$ Hawley, Making Sense of the Alt-Right, 82.

${ }^{21}$ Adorno, The Culture Industry, 85.
} 
of the radio reporter are merely an explosion of the untruth which already lies within the blindness of the facts themselves." 22

The internet memes spread by the Alt-Right during the 2016 presidential campaign exploded untruths about Hilary Clinton. The main aim of spreading such untruths was to assist the victory of their chosen candidate-Donald Trump, who never distanced himself from the Alt-Right during his presidential campaign, and instead interacted with the AltRight online and contributed to spread some of the Alt-Right' untruths by re-tweeting them. However, the question remains how racist and sexist ideas spread by the Alt-Right find such an accepting audience. It is here where we need to turn to Adorno's critical theorizing of laughter.

\section{The False Laughter of the Culture Industry}

Since art has been taken in hand by the culture industry and placed among the consumer goods, its lightheartedness has become synthetic, false and bewitched. No lightheartedness is compatible with the arbitrary contrived. ${ }^{23}$

In the chapter on the culture industry in Dialectics of Enlightenment, titled “The Culture Industry: Enlightenment as Mass Deception”, we find Adorno's most cited critique on the culture industry and the ways it uses laughter to deceive its audience about the real state of affairs in late capitalist societies. Here he reiterates that the culture industry promises the one who consumes it a pleasurable escape from the daily miseries, particularly for those who find themselves being exploited by the capitalist order. However, all the consumer finds in the culture industry is what Adorno calls a pseudo-pleasure, whose core aim is to diffuse the consumer's unhappiness about the state of affairs in the capitalist order, so that she gives up the thought that it is desirable or even possible to resist and change such order. As a result, the culture industry increases consumers' subservience to the capitalist order whose power it contributes to maintain. The culture industry's use of laughter plays a core role in such an undertaking.

\footnotetext{
22 Adorno, The Culture Industry, 86.

${ }^{23}$ Theodor W. Adorno, "Is Art Lighthearted?", in Rolf Tiedemann (ed.), Notes to Literature, Volume Two (New York: Columbia University Press, 1992), pp. 247-253, 251.
} 
Adorno develops his theorizing of laughter in this essay by responding to the early Frankfurt school critical theory thinker Walter Benjamin's argument in "The Work of Art in the Age of Mechanical Reproduction", which suggests that the collective laughter produced by the culture industry in its audience as we find it prevalent in the United States can serve transformative political ends. Benjamin argues that American slapstick comedies or Disney films can trigger a collective laughter in the audience that serves as a therapeutic release of unconscious violent impulses and as such can forestall outbreaks of mass violence. ${ }^{24}$

Adorno thinks otherwise. Although he agrees with Benjamin that there is an emancipatory potential of laughter, he disagrees with Benjamin's one-sided conception of laughter solely as an emancipatory tool, which neglects the ways in which laughter operates as a mechanism of social control and domination. Rather than forestalling mass violence, he argues in a letter to Benjamin (1936) that the laughter of the cinema audience "is anything but salutary and revolutionary; it is full of the worst bourgeois sadism instead". ${ }^{25}$ Rather than releasing unconscious violent impulses in the audience, as Benjamin argues, the collective laughter generated by Disney films and comedies intensifies the audiences' unconscious violent tendencies.

In The Dialectic of Enlightenment he and Horkheimer further argue that before the advent of the culture industry cartoons served as "exponents of fantasy as opposed to rationalism," but now the relations have shifted, and "with the audience in pursuit, the protagonist becomes the worthless object of general violence. The quantity of organized amusement changes into the quality of organized cruelty...(Fun) postpones satisfaction till the day of the pogrom". ${ }^{26}$ For Adorno and Horkheimer the pleasure the audience gets from viewing such organized cruelty is actually no pleasure at all. It is a pseudo-pleasure that is always postponed and generates subjects ready for the violence of the pogrom.

\footnotetext{
${ }^{24}$ Walter Benjamin, "The Work of Art in the Age of Its Technological Reproducibility (Second Version)", in Michael W. Jennings (ed.), Walter Benjamin Selected Writings. Vol. 3, 1935-1938 (Cambridge, MA: Belknap, 2002), p. 118.

${ }^{25}$ Adorno, The Culture Industry, 130.

${ }^{26}$ Horkheimer and Adorno, Dialectic of Enlightenment, 138.
} 
The core aim of such "fun" is to break any resistance to the violence the consumers experience in their daily work-lives. As he puts it, cartoons "hammer into every brain the old lesson that continuous friction, the breaking down of all individual resistance, is the condition of life in this society. Donald Duck in the cartoons and the unfortunate in real life get their trashing so that the audience can learn to take their own punishment". 27

Instead of serving as a moment of resistance to, or transformation of, the status quo, the collective laughter manufactured by the culture industry reinscribes the cruelty and violence of the capitalist order, and trains the laughing audience to uncritically accept such violence. For Adorno, "there is laughter because there is nothing to laugh at...Fun is a medicinal bath. The pleasure industry never fails to prescribe it. It makes laughter the instrument of the fraud practiced on happiness. Moments of happiness are without laughter; only operettas and films portray sex to the accompaniment of resounding laughter. But Baudelaire is as devoid of humour as Hölderlin". 28

In his other writings on the culture industry, Adorno provides us with examples to explain how laughter in capitalist societies turns into a "medicinal bath". He provides the example of a TV comedy where a young, female schoolteacher is not only underpaid but also constantly fined by the authoritarian school principal. As a result she has no money to pay for her meals and she is actually starving. The "funny" situations consist of her trying to hustle food from various acquaintances, but regularly without success. The painful situations into which the heroine runs in her attempts to hustle food provides the amusement of the comedy. Adorno makes clear that the script does not "sell" any idea. Rather, "the "hidden meaning' emerges simply by the way the story looks at human beings; thus the audience is invited to look at the characters in the same way without being made aware that indoctrination is present." 29 Such indoctrination happens when the audience is invited to identify with the charming heroine, who constantly wisecracks.

\footnotetext{
27 Horkheimer and Adorno, Dialectic of Enlightenment, 138.

${ }^{28}$ Horkheimer and Adorno, Dialectic of Enlightenment, 140-141.

${ }^{29}$ Adorno, The Culture Industry, 166-167
} 
Adorno explains that in terms "of a set pattern of identification, the script implies: 'If you are as humorous, good-natured, quick-witted, and charming as she is, do not worry about being paid a starvation wage. You can cope with your frustrations in a humorous way; and your superior wit and cleverness put you not only above material privations, but also above the rest of (wo/)mankind'. In other words, the script is a shrewd method of promoting adjustment to humiliating conditions by presenting them as objectively comical and by giving a picture of a person who experiences even her own inadequate position as an object of fun apparently free of resentment." 30

The culture industry renders the trials and tribulations of mass society humorous by subjecting the audience to laughing at their own inadequacies. It downplays social problems and real human needs, and consumer attention is oriented toward fun and personal entertainment. Laughing about the schoolteacher's desperate attempts to hustle food from her colleagues allows audience members to put an unjust system that pays schoolteachers a starving wage out of mind, and gives them the message that everyone bends to the will of their boss. The script tells the audience members that they don't have to worry about being paid a starvation wage as long as they have a good sense of humor.

Even if their starvation wage makes them experience humiliating conditions in their daily lives, such experiences are, as long as they can be laughed about, not truly objectionable. Since humiliating conditions are not truly objectionable, they don't need to do anything to change them; and since it is humorous how we all experience the same exploitation, there is no need to rebel against such exploitation. As such the core aim of the culture industry's humor is to adjust the exploited to humiliating conditions in capitalism, and with that keep classed power relations intact.

Adorno points out that this latent message of the script cannot be considered as unconscious, but rather as "inobtrusive". As he puts it: "this message is hidden only by a style which does not pretend to touch on anything serious and expects to be regarded as featherweight. Nevertheless, even such amusement tends to set patterns for the members of the audience

${ }^{30}$ Adorno, The Culture Industry, 167. 
without their being aware of it." 31 Also the Alt-Right sets patterns for its potential members by coming across as "featherweight" and as such as not touching on anything serious, although it considers itself with something rather serious - the creation of a white ethno-state in the United States, if necessary by violent means.

\section{The Fun of Desperation}

The more profoundly society fails to deliver the reconciliation that the bourgeois spirit promised as the enlightenment of myth, the more irresistibly humor is pulled down into the netherworld, and laughter, once the image of humanness, becomes a regression to inhumanity. ${ }^{32}$

Hawley points out that older white supremacist groups (which he calls white nationalist) in the United States, such as the Ku Klux Klan, the American Nazi Party, and William Pierce's National Alliance may be considered precursors of the Alt-Right "in the sense that they advocated white nationalism, but the overlap (an obviously significant overlap) largely ends there. Irony and humor-essential to the Alt-Right - were all but nonexistent in these earlier movements. Alt-Right material often has a sense of amused detachment, something not present in any of William Pierce's radio broadcasts." 33

Whereas older white supremacist movements, according to Hawley, came across as bitter, reactionary, and anti-social, the Alt-Right presents itself as a fun movement that uses Internet jargon familiar to tech-savvy millennials. As a result, the Alt-Right "comes across as youthful, lighthearted, and jovial — even if it says the most abhorrent things about racial and religious minorities." 34 I agree with Hawley's argument that lightheartedness makes the Alt-Right come across as less threatening than ear-

\footnotetext{
${ }^{31}$ Adorno, The Culture Industry, 167.

${ }^{32}$ Theodor Adorno, "Is Art Lighthearted?", in Rolf Tidermann (ed.), Notes on Literature, Volume Two (New York: Columbia University Press, 1992), pp. 247-253, 251.

${ }^{33}$ Hawley, Making Sense of the Alt-Right, 24.

${ }^{34}$ Hawley, Making Sense of the Alt-Right, 20.
} 
lier white supremacist groups, which is also the reason why it is a greater threat to mainstream politics than earlier white supremacist groups.

However, to fully grasp the ways in which the Alt-Right uses lightheartedness as a successful recruitment tool, it is necessary to turn to Adorno's critical theorizing of laughter, because it assists us to get a deeper understanding of the interaction of economic and psychological factors which are played out in the humor of the culture industry offered by the AltRight - a humor that pulls us down into the netherworld, and the laughter that resounds from such world turns into a regression to inhumanity.

In Adorno's lesser known article "Is Art Lighthearted?" he questions the possibility of art being lighthearted in the age of the culture industry. ${ }^{35} \mathrm{He}$ starts out with a reference to Schiller's Wallenstein, which ends with the line "Ernst is das Leben, heiter is die Kunst (life is serious, art is lighthearted)". According to Adorno, this line shows that "Schiller secretly anticipates that the situation under the culture industry in which art is prescribed to tired businesspeople as a shot in the arm". ${ }^{36}$ Tired business people need a shot in the arm in the form of shallow entertainment provided by the culture industry to forget about the dullness and alienation of their daily work-life.

Adorno, in the same text, elaborates another aspect of why people in late capitalist societies need "a shot in the arm." He comes back to the poet Hölderlin, whom he and Horkheimer already cite when they discuss the false laugher produced by the culture industry in The Dialectic of Enlightenment. He references Hölderlin's lines "Die Scherzhaften” or "The Ones who make Jokes": Immer spielt ihr und scherzt? Ihr müsst! Oh Freunde! Mir geht diss / In die Seele, den diss müssenVerzeifelte nur (Are you always playing and joking? You have to! Oh friends, this affects me deeply, for only the desperate have to do that). What he means here is that people are constantly joking, because they are verzweifelt (desperate), which is a rather sad scenario.

Referring to the lines of Hölderlin, Adorno points out that when art tries of its own accord to be lighthearted, "it is reduced to the level of human

\footnotetext{
${ }^{35}$ Although Adorno refers in this essay again at the possibility of art's lightheartedness, as we can find it for example in Beckett's plays (p. 248), he is foremost concerned with how humor and jokes make people conform to the status quo.
}

${ }^{36}$ Adorno, "Is Art Lighthearted?", 248. 
need and its truth content is betrayed. Its ordained cheerfulness fits into the way of the world. It encourages people to submit to what is decreed, to comply. This is the form of objective despair". ${ }^{37}$ Much like Hölderlin, Adorno points out that supposedly lighthearted art is nothing else but the result of objective despair. However, beyond Hölderlin, he asserts that such art encourages people to submit themselves to the objective conditions that cause such despair, which underlines its adaptive function.

Also the supposedly "lighthearted art" presented by the Alt-Right is a result of objective despair, one which is particularly experienced by young millennials in the United States today. The liberal capitalist ideology they grew up with has told them that they can have "economic success" and make it in American society if they just try hard enough. However, if we take a closer look at the demographic attributes of the Alt-Right we learn of another story. ${ }^{38}$

The Alt-Right is much younger, on average, than previous iterations of the racial right in America, which one can infer from the youthfulness of the tone of the Alt-Right on the internet as well as conferences that are sponsored by the National Policy Institute (which sponsors the AltRight) where a large number of attendees, mostly male, under the age of thirty-five are present. ${ }^{39}$ Also members of the Alt-Right provide us with some hints about the constitution of the Alt-Right. Richard Spencer, who coined the term "Alt-Right" points out that the Alt-Right supporter is "thirty years old, who is a tech professional, who is an atheist, and who lives on one of the coasts." 40

Asking the question why well educated people are drawn to the AltRight, the Alt-Right member Greg Johnson suggests that the career prospects of college educated whites have declined in the United States: "A growing number of young whites are returning home to live with their parents, remaining unemployed or underemployed for a long time and their

\footnotetext{
${ }^{37}$ Adorno, "Is Art Lighthearted?", 250.

${ }^{38}$ Grasping such attributes require according to Hawley "a lot of guesswork" because the Alt-Right is anonymous and decentralized. Hawley, Making Sense of the Alt-Right, 77.

${ }^{39}$ Hawley, Making Sense of the Alt-Right, 77. The journalist Lauren Fox, who wrote about the 2013 NPI conference, that "perhaps the most surprising thing were the number of young men present, millenials in search of political identity" (cited on p. 77). And the Southern Poverty Law Center noted the large number of millennials at a recent NPI gathering (p. 77).

${ }^{40}$ Cited in Hawley, Making Sense of the Alt-Right, 78.
} 
resentment grows." ${ }^{41}$ The shot the Alt-Right's culture industry offers to put into the arms of young millennials is to help them cope with their feelings of failure, which are the result of them not having lived up to the bourgeois ideal of "making it" in neo-liberal capitalist society.

The Alt-Right prescribes "lighthearted art" in the form of internet memes, to its potential members to help them deal with their objective desperation of not having made it in the neo-liberal capitalist system. But as Adorno points out, this encourages people to continue to comply with such a system, rather than challenging it. To come back to Adorno's citation above-the Alt-Right's "lighthearted art" as presented by its culture industry of the internet, implies nothing else but an "ordained cheerfulness (that) fits into the way of the world. It encourages people to submit to what is decreed, to comply". ${ }^{42}$

One of the ways in which the Alt-Right aims to appear as lighthearted and fun is via adopting the figure of "Pepe the frog" as its mascot. As Hawley points out, "the Alt-Right is, like Pepe, vulgar, irreverent, ironic, and goofy. Despite its innocuous name, the Alt-Right is also, at its core, a racist movement." ${ }^{43}$ The Alt-Right, to add to this observation, is at its core also a sexist movement. Furthermore, although Hawley repeatedly acknowledges the distinctive feature of the Alt-Right as aiming to appear as lighthearted or in the above citation as "ironic and goofy", he fails to outline the ways in which this pretension to not touch on anything serious, sets patterns in its audience to accept the open racism and sexism promoted by the Alt-Right, without their being aware of it.

As an example, in an Alt-Right internet meme, Hitler is depicted as Pepe the frog stating "Kill Jews, man" ${ }^{44}$ By presenting Hitler's call for the genocide on Jews in a humorous way, the meme both expresses the murderous hostility of the Alt-Right toward Jews, while also downplaying the seriousness of such a call. By presenting itself as not touching on anything serious, the meme aims to touch (and thus recruit) new members to support its extremist ideas.

\footnotetext{
${ }^{41}$ Hawley, Making Sense of the Alt-Right, 79.

42 Adorno, "Is Art Lighthearted?", 250.

${ }^{43}$ Hawley, Making Sense of the Alt-Right, 3.

${ }^{44}$ https://www.adl.org/education/references/hate-symbols/pepe-the-frog.
} 
The main goal of the ordained cheerfulness of the entertainment produced by the Alt-Right is to make desperate young people attracted to their extremist ideas, by giving them other groups to look down upon. "Fun" Alt-Right memes reach out to potential members via humor (and anonymity), and spread their message by appearing as "featherweight" or inobtrusive. That such amusement set patterns for the members of the audience without their being aware of it can be seen in the growing Alt-Right movement that accepts its open racism and sexism.

\section{Jokes as the Regression to Inhumanity}

The statement that it is not possible to write poetry after Auschwitz does not hold absolutely, but it is certain that after Auschwitz, because Auschwitz was possible and remains possible for the foreseeable future, lighthearted art is no longer conceivable. Objectively, it degenerates into cynicism, no matter how much it relies on kindness and understanding. ${ }^{45}$

A question in the aforementioned "Is Art Lighthearted?" 46 that Adorno aims to answer is whether comedies or parodies that target fascism can serve transformative political ends. As he explains, "several years ago there was a debate about whether fascism could be presented in a comic or parodistic form without that constituting an outrage against its victims" ${ }^{47}$

In this essay Adorno clarifies his statement in the concluding passage of the 1949 essay, "Cultural Criticism and Society," where he suggests that "to write poetry after Auschwitz is barbaric" 48 For Adorno, because Auschwitz remains a possibility for the foreseeable future, any humor that is turned into a polemical parody of fascism is problematic. ${ }^{49}$

As he further explains, "One cannot laugh at it. The bloody reality was not the spirit (Geist), or evil spirit (Ungeist) that spirit could make

\footnotetext{
45 Adorno, "Is Art Lighthearted?", 251.

46Adorno, "Is Art Lighthearted?", 247-253.

${ }^{47}$ Adorno, "Is Art Lighthearted?", 251.

${ }^{48}$ Theodor W. Adorno, "Cultural Criticism and Society", in Theodor W. Adorno, Prisms, trans. Samuel and Shierry Weber, 17-34, 34 .

${ }^{49}$ Auschwitz stands as a signifier for the genocides committed in the numerous concentration camps during the National Socialist regime.
} 
fun of...comedies about fascism would become accomplices of the silly mode of thinking that considered fascism beaten in advance because the strongest battalions in world history were against it... The historical forces that produced the horror derive from the inherent nature of the social structure. They are not superficial forces, and they are much too powerful for anyone to have the prerogative of treating them as though they had world history behind him and the Führers actually were the clowns whose nonsense their murderous talk came to resemble only afterwards" ${ }^{50}$

Adorno, in this citation, points out that a danger of jokes about fascism is that it induces people to not take it seriously until it's too late, and that comedies about fascism, instead of undermining fascist tendencies in any way, might actually contribute to the forces that brought the horror about. Also the Alt-Right does not have the prerogative of treating the Holocaust in their jokes as though they had world history behind them. The forces that produced the horror of the Holocaust remain slumbering in the social structure of neo-liberal capitalism, and it is the laughter that resounds in the audience about such horror that renders Adorno's argument that Auschwitz remains a possibility as correct.

With this movement's being lighthearted about fascism we can see the regressive tendencies of laugher and fun fully unfolding. Whereas earlier white-supremacist movements in the United States argued that the Holocaust never happened, the Alt-Right treats it as a joke. ${ }^{51}$ Such jokes are not politically subversive in any sense. Rather, as Adorno points out, under the dictates of the culture industry the affirmative character of art "has become omnipresent, and the joke has become the smirking caricature of advertising pure and simple". ${ }^{52}$

Rather than subverting the status quo, the Alt-Right's jokes at the Holocaust affirms society's regressive tendencies. As an example, in response to an online article about a university contest for Holocaust art, the Alt-Right's trolls immediately posted absurd comments about their supposed family's experiences in concentration camps in the article's comment section. The comments treated experiences of Holocaust survivors

\footnotetext{
50Adorno, "Is Art Lighthearted?", 251-252.

${ }^{51}$ Hawley, Making Sense of the Alt-Right, 25.

52 Adorno, "Is Art Lighthearted?", 250.
} 
as a joke. One such joke reads: "All six of my grandmothers were survivors. They avoided being gassed by playing alto saxophone and electric piano solos for the guards while hiding in a pile of rubble." 53

This Alt-Right joke serves as what Adorno calls a "medicinal bath" that aims to numb potential consumers of the joke of the suffering of others, as well as their own objective despair in late capitalist society. As he puts it, "(a)musement means putting things out of mind, forgetting suffering, even when it is on display." 54 In this amusement about the Holocaust the Alt-Right aims at putting suffering out of sight in two ways.

First, even as the suffering of Jewish concentration camp survivors is on display, by presenting their survival strategies in a humorous way, any such suffering is put out of mind. The joke also serves as an attack on an important attempt to remember the Holocaust and the immense suffering it brought to Jews and other groups of people. By mocking their survival strategies one can again deny them support for their suffering.

Second, the "medicinal bath" of the joke also aims to cover over the Alt-Right joke consumers' own suffering. The joke is a medicinal bath for the cheated happiness of (potential) Alt-Right consumers, who have been promised happiness in the United States if they work hard and go to college. However, instead of such happiness they find themselves without a job and back at their parent's house, in whose eyes and the eyes of society are failures. The joke offers them a shot in their arms to numb them of their own objective despair. To make fun about somebody else also assists them to feel better about themselves, which leads us to the connection between Trumpism and the Alt-Right.

\section{The Laughing Connection Between Trump and the Alt-Right}

To laugh at something is always to deride it, and the life which...in laughter breaks through the barrier, is actually an invading barbaric life, self-assertion prepared to parade its liberation from any scruple when the social occasion arises. Such a laughing audience is a parody of humanity. Its members are

${ }^{53}$ Hawley, Making Sense of the Alt-Right, 25.

${ }^{54}$ Horkheimer and Adorno, Dialectic of Enlightenment, 116. 
monads, all dedicated to the pleasure of being ready for anything at the expense of everyone else. Their harmony is a caricature of solidarity. ${ }^{55}$

Hawley repeatedly makes the argument that Trump, his followers and mainstream Republicans (which more and more overlap with Trump followers as many who were critical of him now support him to have a say in his administration) ought not to be confused with the Alt-Right, and that Trump is not a neo-Nazi. Although I grant Hawley his claim that Trump supporters and mainstream Republicans aren't necessarily Alt-Right neoNazis, this argument shouldn't obscure the fact that similar mechanisms play a key role in all of these camps.

The role of jokes and humor underscores the connection between the Alt-Right, Trump and his followers, as well as mainstream Republicans, which Hawley aims to sever in his book. The laughter of the audience of Trump followers which resounds in response to one of Trumps' many openly racist or sexist jokes, is connected to the laughter of a mainstream conservative to an "off color joke" and the laughter that resounds in the consumer of the Alt-Right culture industry of jokes. They all have in common that the resounding laughter at such jokes is an invading barbaric life that sells itself as lighthearted amusement.

The more hidden laugher resounding as a response to "off color" racist and sexist jokes of Republicans prepared the way for the open laughter of Trump supporters at the same jokes, and finds its culmination in the openly hostile Alt-Right jokes. All of them have in common that the harmony established through laughter amongst those who laugh is nothing else but a caricature of solidarity. Furthermore, the laughter of mainstream Republicans, Trump supporters and consumers of Alt-Right jokes have in common that they aim to deride what is laughed at as a means to make them feel better about themselves.

In Freud's Group Psychology and the Analysis of the Ego, we further learn about the deeper psychological mechanisms of humor and jokes via his concept of ego-ideal replacement. In this essay Freud points out that initially the narcissistic ego believes itself to be fully self-sufficient. However, when it is met with challenges in its environment that it cannot always

${ }^{55}$ Horkheimer and Adorno, Dialectic of Enlightenment, 141. 
meet, its splits part of itself off-which is the ego ideal. However, the split between the ego ideal and the ego "cannot be borne for long either, and has to be temporarily undone. In all renunciations and limitations imposed upon the ego a periodical infringement of the prohibition is the rule." 56

In festivals the split between the ego and the ego ideal is temporarily undone, which results in the cheerful character of the festival. I have previously argued that Trump had and continues to have such an appeal for people, because he allowed his supporters a "Trump festival." 57 By replacing their ego-ideal (which implies in neo-liberal capitalist society to have economic success) with the chosen leader, which happens via introjection, his followers could get rid of the feelings of failure and frustration generated by not being able to live up to the neo-liberal capitalist standard of economic success and feel once again satisfied with themselves.

Furthermore, Freud explains that our mental existence is comprised "into a coherent ego and into an unconscious and repressed portion which is left outside." 58 When subjects are awake they make use of what Freud calls "special artifices" for allowing "what is repressed to circumvent the resistances and for receiving it temporarily into our ego to the increase of our pleasure. Jokes and humor, and to some extent the comic in general, may be regarded in this light". ${ }^{9}$ Insofar as the ego-idea is the chief agent of repression, jokes and humor allow the temporary undoing of the split between the ego and the ego ideal, which leads to an increase in pleasure and a temporarily relief of the ego ideal and its demands upon the ego.

Trump frequently uses racist, sexist and classist jokes at his gatherings with his followers. The use of jokes at the Trump festival and the jokes of the Alt-Right have the same aim-to undo the split between the ego ideal and the ego, and to make frustrated egos feel good about themselves

\footnotetext{
56 Sigmund Freud, Group Psychology and the Analysis of the Ego, trans. James Strachey (London and New York: W. W. Norton, 1989), p. 81.

${ }^{57}$ See Claudia Leeb, "A Festival for Frustrated Egos: The Rise of Trump from an Early Frankfurt School Critical Theory Perspective", in Angel Jaramillo and Sable Marc (eds.), Trump and Political Philosophy: Patriotism, Cosmopolitanism and Civic Virtue (New York: Palgrave Macmillan, 2018), pp. 297-314; Claudia Leeb, "Mass Hypnoses: The Rise of the Far Right from an Adornian and Freudian Perspective", Berlin Journal of Critical Theory, Vol. 2, No. 3 (July 2018): 59-82.

${ }^{58}$ Freud, Group Psychology and the Analysis of the Ego, 80.

${ }^{59}$ Freud, Group Psychology and the Analysis of the Ego, 81.
} 
again. For both camps, jokes are an effective recruitment tool because they offer members a periodical relief from the demands of the ego ideal.

Young millennials are attracted to the Alt-Right, because it makes them feel better about their objective despair and allows them (temporarily at least) a relief from nagging feelings of being regarded as a failure in bourgeois society. Jokes and the humorous attitude of the Alt-Right allows its followers to numb any feelings of objective despair and instead feel pleasure. Furthermore, as Adorno puts it, "to laugh at something is always to deride it," and Alt-Right jokes express contempt for others, thus making its followers feel better about themselves. This is the same reason why Trump followers are attracted to Trump.

Hawley repeatedly asserts that the Alt-Right shares few premises with mainstream conservativism, but he does acknowledge that mainstream conservativism may have opened the door for the Alt-Right with its "ferocious opposition to all things related to political correctness and its skepticism about mass immigration". ${ }^{60}$ Furthermore, even Anti-Alt-Right conservatives, such as the political theorist Ben Shapiro, have built a career on attacking political correctness, and he might thus have contributed to paving the way for the rise of the Alt-Right. ${ }^{61}$

Conservatives have argued that they are a movement that is politically incorrect, and that they do not "get worked up about off-color jokes; conservatives are tough and 'tell it like it is," so they are edgy, and "those that complain about offensive speech are simply overprotected 'snowflakes' who cannot take a joke". ${ }^{62}$ We find such supposed "toughness" continued in the attacks on political correctness and the "medicinal bath" of racist and sexist jokes at Trump rallies, and, as an outgrowth of that, in the jokes of the Alt-Right. There is then a connection between conservatives and Trump's attack on PC culture and the false humor and jokes used by the Alt-Right to recruit new members.

There is also a problem with Hawley's attempt to make a somewhat sharp distinction between the Alt-Lite and the Alt-Right. For him, the Alt-Lite, which is according to him composed of Trump followers, shares

\footnotetext{
${ }^{60}$ Hawley, Making Sense of the Alt-Right, 50.

${ }^{61}$ Hawley, Making Sense of the Alt-Right, 43.

${ }^{62}$ Hawley, Making Sense of the Alt-Right, 42-43.
} 
"merely" the Alt-Right's attack on PC culture and its opposition to immigration, but the Alt-Lite is for him much different from the Alt-Right, because it falls short of promoting a white ethno-state, though this seems to be as much a "public relations" strategy to dodge criticism, as is the use of humor (rather than overt hate).

However, what the attack on PC culture entails in the Alt-Lite, Trump supporters as well as mainstream conservatives, is to have a license via the use of humor and "fun" to be openly racist, sexist and classist, without fearing any consequences. It is such license that liberates these interconnected consumers of jokes from any scruple when the social occasion arises, and it is this liberation that makes Auschwitz a possibility in the present.

\section{False Projections}

In "Elements of Anti-Semitism", which is a chapter in the Dialectics of Enlightenment, Adorno explains the centrality of false projection in fascist movements. False projection, which is for Adorno the essence of AntiSemitism, is nothing else but the projection of one's own unhappiness onto the prospective victim. ${ }^{63}$ In false projection, impulses, which the subject cannot admit to herself, are attributed to the object-the prospective victim. After introducing the concept of false projection, I explain how false projection is central in the Alt-Right's attacks on Jews and others.

In this text Adorno introduces Freud's distinction between the conscious ego, the id (the unconscious) and the super-ego (our moral conscience) to explain false projection. He points out that the ego, under the pressure of the super-ego, projects aspects from the id that are even dangerous to the id itself as evil intentions onto the outside world. ${ }^{64}$ As an example, the fascist's portrait of Jews as an "opposing race", that wants total possession and unlimited power, is according to Adorno nothing else but its own self-portrait. Here the fascists own unconscious desires-its longing for total possession and unlimited power-is projected upon the Jews, and the guilt about wanting unlimited power is transferred to the Jews. ${ }^{65}$

\footnotetext{
${ }^{63}$ Horkheimer and Adorno, Dialectic of Enlightenment, 187/1.

${ }^{64}$ Horkheimer and Adorno, Dialectic of Enlightenment, 192.

${ }^{65}$ Horkheimer and Adorno, Dialectic of Enlightenment, 168.
} 
In what ways is false projection connected to jokes? Here it is important to note that Freud at times uses the concept of the ego-ideal as interchangeable with the super-ego, which also provides a hint of the ways in which false projections and jokes are connected. As explained in the previous section, jokes allow one to circumvent those aspects of the ego that the ego, confronted with the ego-ideal, had to repress, which one experiences as a pleasurable release when confronted with the joke. In false projection, instead of allowing unconscious impulses and instincts to appear in the conscious ego, they are projected onto the outside world-onto the prospective victim.

Such false projection is salient in another successful meme the Alt-Right used during the presidential elections. The meme implied the "placement of three parentheses around Jewish names- (((Albert Einstein $)))$ for example. The purpose of parentheses was to highlight the large number of Jewish Americans in media and academia." ${ }^{\text {"6 }}$ Furthermore, an Alt-Right follower created a plug-in, which put automatically parentheses around Jewish-sounding names on web pages. Although the plug-in was quickly removed by Google for violating its hate speech policies, it was nonetheless downloaded by thousands of people.

There is a problem with Hawley's uncritical argument in the citation above that the meme was used to "highlight the large number of Jewish Americans in media and academia", which he reiterates later in the text by stating that the core goal of the meme was to "draw attention to the overrepresentation of Jews in media." 67 Rather, much like the Nazis during the Third Reich, the core aim of the "fun" meme was to construct Jews, via the culture industry of the internet, as the "opposing race" who have (via media and academia) supposed unlimited power and possession. The deeper aim of such construction was to project the Alt-Right's own longing of unlimited power and possession, which became vividly salient in Richard Spencer's speech, onto Jews and others, that is onto their prospective victims.

After Trump's election, during the National Policy Institute conference that occurred on November 19, 2016, Spencer, who coined the term

\footnotetext{
${ }^{66}$ Hawley, Making Sense of the Alt-Right, 83.

${ }^{67}$ Hawley, Making Sense of the Alt-Right, 83.
} 
"Alt-Right" gave the following speech: "As Europeans, we are uniquely, at the center of history. We are, as Hegel recognized, the concept of world history. No one mourns the great crimes committed against us. For us, it is conquer or die. This is a unique burden for the white man, that our fate is entirely in our hands. And it is appropriate because within us, within the very blood in our veins as children of the sun lies the potential for greatness. That is the great struggle we are called to. We were not meant to live in shame and weakness and disgrace. We were not meant to beg for moral validation from some of the most despicable creatures to pollute the soil of this planet. We were meant to overcome-to overcome all of it. Because that's natural for us. Because for us, as Europeans, it's only normal again, when we are great again." ${ }^{\prime 68}$

Spencer's concluding statement: "Hail Trump. Hail our people. Hail victory," was furthermore greeted by some people in the audience by raising their right arm in the Nazi salute. In his reading of the talk, Hawley points out that "words like 'conquer' only reinforce the view that the Alt-Right really is about white supremacy and the subjugation of nonwhites." ${ }^{69}$ However, there is something else going on. Similar to the fascists, who defended the plundering of Jews by constructing a complicated ideology of being saviors of the family, the fatherland, and mankind, also the Alt-Right suggests that they will according to "world history" become saviors of the world. ${ }^{70}$

Furthermore, in this speech we find the Alt-Right's own longing for total possession and power, which they then project onto the "the most despicable creatures to pollute the soil of this planet", which is for the Alt-Right, much as it was for the Nazis before them, the Jews and anyone not-white. In this sentence we find racism and an attack on PC culture going together. The Alt-Right is projecting on the Jews and others, via their myth of "white genocide" — another successful Alt-Right meme, which Trump retweeted during his presidential campaign - that they are the ones under attack, when really it is they who want to attack others. Such false projection also functions as a justification for their own aggression

\footnotetext{
${ }^{68}$ Cited in Hawley, Making Sense of the Alt-Right, 134.

${ }^{69}$ Hawley, Making Sense of the Alt-Right, 134.

${ }^{70}$ Horkheimer and Adorno, Dialectic of Enlightenment, 171.
} 
and hostility, in the name of self-defense (as in, they either conquer others or die).

Their core aim is to make those who feel objective despair (e.g. white males), which is salient in the acknowledgement that "we were not meant to live in shame and weakness and disgrace", believe they can return to a supposedly "natural" state of "greatness". Trump's repeatedly reiterated and mind-numbing assertions that he will "make America great again" in connection with his racist and sexist jokes paved the way for the Alt-Rights' view of white supremacy to enter national (and international) politics.

It is this intimate connection between fascism and Trumpism, which we see played out in Trump's as well as the Alt-Right's use of humor and jokes as means for recruiting new members, that render an inkling of horrible truth in Spencer's "Hail Trump" and the greeting of it by Alt-Right members raising their right arm in the Nazi salute. It is such connection that we need to keep in mind in our attempts to fight fascism and Trumpism.

\section{References}

Theodor W. Adorno, "Cultural Criticism and Society", in Theodor W. Adorno (ed.) and Samuel and Shierry Weber (trans.), Prisms (Cambridge: The MIT Press, 1990), pp. 17-34, 34.

Theodor W. Adorno, The Culture Industry: Selected Essays on Mass Culture, ed. J.

M. Bernstein (London and New York: Routledge, 1991).

Theodor W. Adorno, "Is Art Lighthearted?", in Rolf Tiedemann (ed.), Notes to Literature, Volume Two (New York: Columbia University Press, 1992), pp. 247-253, 251.

Walter Benjamin, "The Work of Art in the Age of Its Technological Reproducibility (Second Version)", in Michael W. Jennings (ed.), Walter Benjamin Selected Writings. Vol. 3, 1935-1938 (Cambridge, MA: Belknap, 2002), p. 118.

Sigmund Freud, Group Psychology and the Analysis of the Ego, trans. James Strachey (London and New York: W. W. Norton, 1989), p. 81.

George Hawley, Making Sense of the Alt-Right (New York: Columbia University Press, 2017). 
Max Horkheimer and Theodor W. Adorno, Dialectic of Enlightenment, trans. John Cumming (New York: Continuum Publishing, 2002).

Simon Jarvis, Adorno: A Critical Introduction (New York: Routledge, 1998).

Claudia Leeb, "A Festival for Frustrated Egos: The Rise of Trump from an Early Frankfurt School Critical Theory Perspective", in Angel Jaramillo and Sable Marc (eds.), Trump and Political Philosophy: Patriotism, Cosmopolitanism and Civic Virtue (New York: Palgrave Macmillan, 2018a), pp. 297-314.

Claudia Leeb, "Mass Hypnoses: The Rise of the Far Right from an Adornian and Freudian Perspective", Berlin Journal of Critical Theory (Vol. 2, no. 3, July 2018b), pp. 59-82.

Claudia Leeb is an Associate Professor in political theory in the School of Politics, Philosophy, and Public Affairs at Washington State University. She works at the intersection of early Frankfurt school critical theory feminist theory, and psychoanalysis to address questions of power and rebellion. She is the author of The Politics of Repressed Guilt (2018, Edinburgh University Press), Power and Feminist Agency in Capitalism (2017, Oxford University Press), Working-Class Women in Elite Academia (2004, Peter Lang Publisher) and Die Zerstörung des Mythos von der Friedfertigen Frau (1998, Peter Lang Publisher). She has articles published in Political Theory, Theory \& Event, Perspectives on Politics, Constellations, Social Philosophy Today, The Good Society, The Berlin Journal of Critical Theory, Open Cultural Studies, Philosophy \& Social Criticism, and Radical Philosophy Review. She has also contributed several book chapters to anthologies on Frankfurt school critical theory. 